\title{
Pengembangan Sentra Industri Ukm Krupuk Terasi Dalam Menghadapi Era New Normal: Studi Ukm Budi Jaya Makmur Di Desa Buden- Lamongan
}

\author{
Sabilar Rosyad,Wisnu Priambodo \\ Fakultas Ekonomi Manajemen. Universitas Islam Lamongan \\ Email: rosyadabil4@unisla.ac.id \\ wisnupriambodo@unisla.ac.id
}

\begin{abstract}
ABSTRAK
Usaha Kecil Menengah (UKM) mempunyai peran penting dan strategis bagi pertumbuhan ekonomi negara, baik negara berkembang maupun negara maju. Pada saat krisis ekonomi berlangsung di Indonesia, Usaha Kecil Menengah merupakan sektor ekonomi yang memiliki ketahanan paling baik. Kemampuan UKM perlu diberdayakan dan dikembangkan secara terus menerus dengan berusaha mereduksi kendala yang dialami UKM, sehingga mampu memberikan kontribusi lebih maksimal terhadap peningkatan kesejahteraan masyarakat. Penelitian ini menunjukkan bahwa penyebab menurunya penjualan adalah dampak dari pandemi Covid-19, kenaikan harga bahan baku, dan kurangnya inovasi produk. Oleh karena itu perlu adanya pembinaan dari pemerintah dalam mengembangkan inovasi produk dan inovasi dalam pemasaran. Sehingga eksistensi sentra industri kerupuk terasi dapat berkembang dan membuka lapangan pekerjaan bagi warga sekitar serta meningkatkan pendapatan asli warga desa buden..
\end{abstract}

Kata Kunci : New Normal, Kerupuk Terasi, Startegi, UKM.

\section{PENDAHULUAN}

Usaha Kecil Menengah (UKM) mempunyai peran penting dan strategis bagi pertumbuhan ekonomi negara, baik negara berkembang maupun negara maju. Pada saat krisis ekonomi berlangsung di Indonesia, Usaha Kecil Menengah merupakan sektor ekonomi yang memiliki ketahanan paling baik. Kemampuan UKM perlu diberdayakan dan dikembangkan secara terus menerus dengan berusaha mereduksi kendala yang dialami UKM, sehingga mampu memberikan kontribusi lebih maksimal terhadap peningkatan kesejahteraan masyarakat. buden adalah salah satu UKM yang berdiri sejak 2010 ketika beberapa warga memulai pembuatan kerupuk terasi. Pada awal nya hanya satu warga yang memulai pembuatan kerupuk terasi ini. Tapi dengan berjalan nya waktu banyak warga yang mencoba membuat kerupuk terasi ini, mengingat pada saat itu keuntungan yang di rasa sangat menjanjiakan untuk menunjang ekonomi semua warga. Dari sini satu demi satu warga desa buden mulai menggeluti usaha kerupuk terasi sampai saat ini.

\section{METODE PELAKSANAAN}

Penelitian ini menggunakan desain deksriptif. Tujuan desain penelitian deskriptif sebagaimana dijelaskan oleh Sakaran (2008) adalah untuk mendeskripsikan aspek-aspek yang releven dari suatu fenomena yang dipelajari peneliti dari seorang individu, organisasi, industri, atau perspektif lain. Dengan demikian penelitian deskriptif menyajikan data dalam bentuk yang sangat bermakna sehingga membantu untuk memahami karakteristik dari suatu kelompok, membantu dalam pemikiran secara sistimatis tentang aspek-aspek dalam situasi tertentu, menyediakan ide untuk pencarian dan penelitian lebih lanjut, dan 
membantu dalam pengambilan keputusan. Dalam hal ini konteks yang dipelajari adalah sentra industri kerupuk terasi.Desain penelitian menunjukkan proses penelitian mulai dari perencanaan sampai dengan analisis untuk memperoleh temuan penelitian.

\section{HASIL DAN PEMBAHASAN}

Berdasarkan UKM Budi Jaya Makmur merupakan sentra industri yang ada di desa buden lamongan. Sejak awal 2010 sudah dilakukan pembuatan kerupuk terasi oleh masyarakat Desa Buden. Sejak 7 mei 2010 pembuatan kerupuk terasi di Desa Buden Kab. Lamongan membuat UKM dengan nama nama Budi Jaya Makmur yang beranggotakan keluarga dari bpk. Sahid. Jumlah anggota tidak mengalami peningkatan pada saat itu.

Sampai dua tahun, baru pada tahun ketiga ada penambahan anggoota menjadi 10 anggota. Yang berasal kan dari tetangga. banyak warga yang berkaloborasi dalam membuat kerupuk terasi, sehingga omzet penjualan mengalami peningkatan. Dalam membuat kerupuk terasi, dukungan dari para tetangga sanagat besar pada saat itu. Mulai dari pengembangan rasa ataupun bentuknya, pembelian bahan baku yang terkordinir, serta adanya penentuan harga pasar yang seragam sehingga terciptanya persaingan pasar yang sehat.

Namun sejak terjadinya peristiwa Covid-19 yang terjadi pada tahun 2020, pengunjung atau pembeli yang datang langsung atau memesan lewat media mulai menurun drastis. Pandemi Covid-19 menjadikan tamparan keras dan penghalang pemasran kerupuk terasi pada saat ini. Sampai - ada yang gulung tikar karena tidak adanya pesanan sama sekali. Beberapa di antara mereka yang masih bertahan hanya beroperasi berdasarkan pesanan dan pelanggan tetap saja.Faktor lain yang menyebabkan menurunnya pembeli kerupuk terasi di Buden ini adalah banyak pemberitaan media massa bahwa covid-19 bisa menular melalu makanan yang mana memunculkan persepsi kepada masyarakat luas bahwa kerupuk terasi juga bisa jadi media penularan covid-19. Padahal secara produksi, kerupuk terasi di buat dengan aman dan higienis. Sampai hari ini, sentra industri kerupuk terasi di buden itu pun sama sekali belum tersentuh Covid-19.

Bencana pandemic Covid-19 yang terjadi pada tahun 2020 sangat berdampak pada pertumbuhan UKM Kerupuk terasi yang letak nya berdekatan dengan area gresik dan Surabaya yang termasuk Zona merah nasional bencana pandemic Covid-19.

Namun perbaikan penanggulanan dan perekonomian terus dilakukan oleh pemerintah juga UKM Budi Jaya Makmur yang menaungi usaha pembuatan kerupuk Terasi. Banyak usaha yang telah dilakukan, salah satunya yakni dengan membuat websait atau berjualan secara online di media-media yang menyediakan akses jual beli online. Tidak hanya media online, tetapi pihak pemilik sendiri juga terus memperbaiki usahanya masing-masing dengan menyambung komunikasi dengan para pelanggan setelah pemerintah mengumumkan New Nrmal, juga melakukan strategi menjemput bola.

Dalam setiap pelaksanaan program tidak akan berjalan dengan mulus, pasti mengalami kendala dan hambatan. Tetapi di sisi lain juga terdapat faktor pendorongnya yang dapat mensukseskan pelaksanaan program. Sehingga dapat diperlukan langkah untuk menanggulagi hambatan dan perlu memikirkan langkah lagi untuk memudahkan pelaksanaan program.Implementasi Rencana Strategi Diskoperindag dalam memberdayakan industri kecil di seluruh lamongan harus di apresisai sebesar - besar nya. Peran Diskoperindag Dalam Mengembangkan industry UKM. Strategi yang sudah dilakukan adalah ; 1) Pembinaan Desain produk, berdasarkan hasil temuan dilapangan pelaksanaan pembinaan desain produk 
kurang mendapat perhatian dari Diskoperindag Kabupaten lamongan. Hal ini terbukti dari pembinaan terhadap pengusaha industri kecil krupuk terasi cuma terjadi pada waktu itu dan itu pun tidak secara berkelanjutan. 2) Pembinaan Dalam Bidang Promosi sehingga pengusaha industri kecil dapat membuka akses keberbagai pasar sehingga jangkauan nya lebih luas lagi dalam peluang pemasaran produknya.

Perkembangan Tingkat Pendapatan Pengusaha Melalui Kegiatan Pemberdayaan UKM Kerupuk Terasi bisa dilihat Dari Segi Produksi Program pemberdayaan yang dilakukan Diskoperindag memperoleh hasil yang sangat baik. Dapat dilihat bahwa kenaikan pendapatan para pengusaha industri UKM kerupuk tersasi Di new Normal ini naik hingga 10\%. Para pelaku usaha mengaku dulu penghasilan perbulan hanya 8 juta perbulan setelah adanya pemberdayaan bisa mencapai 15 juta perbulan. Yang paling banyak menyumbang pada penghasilan para pelaku usaha adalah kegiatan pameran dan promosi ke berbagai media online yang gencar dilakukan.

Faktor-faktor yang menjadi pendukung dan penghambat dari implementasi rencana strategis diskoperindag dalam pemberdayaan industri kecil lamongan khususnya pada UKM kerupuk terasi, yang di dalamnya meliputi: (1) Faktor Internal Dari Implementasi Rencana Strategis yang mempunyai faktor Pendukung Antara lain : adanya Rencana Strategis dan Rencana Kerja bagi SKPD yang terkait dengan pemberdayaan industri kecil, meningkatkan pelaksanaan Pembinaan Desain Produk dan Pembinaan Promosi terdapat di Rencana Kerja, pemerintah yang selalu pro aktif dalam pemberdayaan industri kecil, bantuan berupa mesin jahit kepada pengusaha industri kecil. Sedangkan faktor Penghambat antara lain : kurangnya frekuensi pelatihan desain produk kepada para pelaku usaha kerupuk terasi, banyak para pelaku usaha kerupuk terasi yang keluar dan beralih kepekerjaan lain.

Di Era new normal ini diharapkan para pelaku usaha ukm kerupuk terasi bisa mengembangakan lagi usaha nya, menjadikan new normal ini sebagai lembaran baru memulai usaha Ukm kerupuk terasi dengan lebih baik lagi. Sehingga bisa memberikan lapangan pekerjaan yang lebih luas lagi bagi masyrakat di desa buden.

\section{KESIMPULAN DAN SARAN}

Kesimpulan dari penelitian ini menunjukkan bahwa penyebab menurunya penjualan adalah dampak dari pandemic Covid-19, kenaikan harga bahan baku, dan kurangnya inovasi desain produk. Oleh karena itu perlu adanya pembinaan dari pemerintah dalam mengembangkan inovasi desain produk dan inovasi dalam pemasaran. Sehingga eksistensi Ukm Budi jaya Makmur selaku pembuat kerupuk terasi dapat berkembang dan membuka lapangan pekerjaan bagi warga sekitar serta meningkatkan pendapatan asli warga desa buden Kec. Deket Kab. Lamongan.

\section{DAFTAR PUSTAKA}

Departemen Perdagangan Republik Indonesia. 2008. Pengembangan Ekonomi Kreatif Indonesia 2025.

www.kompas.com/tren/read/2020/05/20/063100865/mengenal-apa-itu-new-normal-di-tengahpandemi-corona-?page=all

Direktorat Penelitian dan Pengabdian Kepada Masyarakat Direktorat Jenderal Pendidikan Tinggi Kemendikbud RI. 2013. Pedoman Penelitian Edisi IX. 
F. R. David. 2011. Strategic Management Concepts and Cases. Edisi 10. Pearson Prentice Hall, Upper Saddle River. New Jersey.

Halik, A., Perdana, D., \& Prasnowo, M. A. 2016. Peningkatan Usaha Pengepul Barang Bekas Di Kota Surabaya. JPM17: Jurnal Pengabdian Masyarakat. 2(01). Prasnowo, M. A., \& Hidayat, K. 2017. Kajian Pemberdayaan Masyarakat Dengan Teknologi Tepat Guna (Produksi Olahan Bambu).

Gusti Adriansyah, 2017. Pengembangan Sentra Industri Tas Dan Koper Tanggulangin Dalam Menghadapi Mea. Jurnal Darussalam; Jurnal Pendidikan, Komunikasi dan Pemikiran Hukum Islam Vol. IX, No 1: 24-31. September 2017. ISSN: 1978-4767

Prasnowo, M. A., Khomaruddin, A., \& Hidayat, K. 2017. Strategi Pengembangan Sentra Industri Kecil Menengah Produksi Krupuk. Teknika: Engineering and Sains Journal. 1 (1), 17-24.

Sakaran, Uma. 2008. Research Methods for Business: A Skill-Building Approach. Second Edition. New York: John Willey \&Sons.

Sutaryo. 2004. Pengaruh Karakteristik Inovasi terhadap Adopsi Tekonologi Internet oleh UKM. Jurnal ekonomi dan Keuangan, Vol. 2, No.2 (Juni), pp 290.

Soetrisno, N. 1999. Pengembangan UKM, Ekonomi Rakyat dan Penanggulangan Kemiskinan. Jakarta: Publikasi Ilmiah.

Tambunan, Tulus. 2001. Industrialisasi di Negara Sedang Berkembang, Kasus Indonesia. Jakarta: Ghalia Indonesia.

T. Pudjadi, Kristanto, dan A. Tommy. 2007. Analisis untuk Perencanaan Strategi Sistem dan Teknologi Informasi pada PT. Ritrans Cargo. Dipesentasikan pada Seminar Nasional Aplikasi Teknologi Informasi. Yogyakarta: 16 Juni 2007

https://www.liputan6.com/bisnis/read/4312271/ingin-bisa-terususaha-di-masa-new-normalini-5-langkah-nyata-yang-bisa-kamu-lakukan 